\title{
Aspects of the working life of women in the nursing profession in South Africa: survey results
}

\author{
BJ Erasmus, DCom \\ School of Management Sciences, Unisa \\ T Brevis, DCom \\ School of Management Sciences, Unisa
}

Keywords: working environment of nurses; pay-related issues; training opportunities; medical insurance; equal opportunities.

\section{Correspondence address:}

\section{Prof T Brevis}

School of Management Sciences

POBox 392

Pretoria

0001

Tel No:(012)429-4764 or 0824497504 e-mail address: brevit@unisa.ac.za

\section{Abstract: Curationis 28(2): $51-60$}

This article reports on a survey done among nurses registered with the South African Nursing Council. The survey was carried out in the last quarter of 2003. The purpose of the survey was to investigate aspects of the working life of women in the nursing profession in South Africa and to make recommendations on how their working environment could be improved. The important findings were that pay-related issues dominate as the main problem at work. Improving pay scales and being paid according to extra experience, responsibilities and qualifications could improve the nurses' working environment. Furthermore, training opportunities, medical insurance and equal opportunities should be addressed as a matter of urgency. In general, respondents had a positive attitude towards their job, which leaves the impression that nurses still regard their jobs as something they do for the sake of a service to the community and not only for the money they earn.

\section{Introduction}

The position of women in the workplace has changed significantly since the implementation of a new dispensation in South Africa in 1994. The new constitution paved the way for women to take their rightful place in the workplace as equal partners of men and their participation in the labour market has increased significantly during the past few years. In 1970 the workforce consisted of $77 \%$ men and $23 \%$ women active in the South African economy. By 1995 this figure had changed to $57 \%$ men and $43 \%$ women respectively and by 2001 the figure had become $53 \%$ men and $47 \%$ women (Statistics South Africa 2001:7.1). The role of women in the South African economy should not be underestimated. The fact that women are joining organisations as managers and professionals has prompted studies on various aspects of the importance of their contribution in general. Not only do they make a significant contribution to the alleviation of the skills shortage in South Africa, but the manner in which they make this contribution is also noteworthy. The trend towards combining a career with marriage and parenthood has run parallel with the opening up of jobs as a result of the demographic change in organisations, which has affected women, men and families. Dual income families have become increasingly prevalent as a result of the financial pressures brought about by higher first world standards. The shift from production-oriented to services-, technology- and information-oriented industries has opened the door for women to enter the labour economy on a large scale (Malan 2004:19).

In the nursing profession, women are predominant in number, with males representing a small percentage of the total workforce. According to Malan (2004:19), there were 109194 nurses registered with the South African Nursing 
Council (SANC) in 1980. In 1990, the figure grew to 148558 and in 2001 , a total of 173332 nurses were registered with the SANC. In spite of the growth in the number of nurses registered with the SANC, South Africa is experiencing a huge shortage of nurses, with 30974 vacant posts in 2001 in the country. Most of these vacancies are in rural areas. The main reasons for this shortage are that fewer nurses complete their studies than the number actually needed in the health care sector and more and more nurses leave the country for better salaries and benefits (Malan 2004: 19). Unless drastic steps are taken to improve the working life of women in the nursing profession, this shortage will have a negative impact on the general health care services of the country.

Because women in the nursing profession are important role-players in the present labour market and particularly in the healthcare services of South Africa, this investigation could contribute significantly to our understanding of how their working life and their perceptions of that life could impact upon the provision of quality health care in this very important industry.

\section{The objective of the study}

The objective of this study was to investigate aspects of the working life of women in the nursing profession in South Africa and to make recommendations on how their working environment could be improved.

\section{Changes in the health care environment}

The nursing profession has played an important role throughout history as an essential instrument in the preservation of life. The purpose of the nursing profession is to meet people's health needs. Hence, as health needs change, so too must health care.

Different factors affect current health care services in South Africa, such as economic and political changes, population growth, the rate of technological advances and ongoing global problems such as hunger and poverty. The health care environment is changing rapidly, causing fundamental changes in health care organisations and ultimately changing the working life of nurses. Some of these changes are outlined below (Jooste 2003:7).
- New trends have emerged in society, including new demographic patterns, with people living longer and healthier lives and the increasing population of very old people requiring nursing care.

One of the negative results of the HIV/ AIDS pandemic is that thousands of orphans are being left without parents or homes.

- The public is becoming more knowledgeable about health matters, and governments are therefore increasingly demanding that patients' views be sought and that equal partnerships be developed between patients and health care professionals.

- A factor that continues to constrain the health care system is finance, and its impact on the resources available and the mobility of the labour force. Patient/client periods of stay in hospitals are greatly reduced with managed care principles, and early discharge patterns are evident. Shifts in the location of care, for instance from a hospital setting to a primary health care clinic, and the transfer of patients between acute and chronic settings and then back to their homes, have resulted in far more work and greater responsibility for general practitioners and primary health care practitioners. Nurse practitioners are placed mainly in the acute or community settings.

- The ethical codes and oaths of health care professionals. with their rules of conduct, may have to be extended and augmented in future to include ethical theories developed to suit difficult contemporary health care situations. The objectives of the nursing profession - to save life, to cure disease, and to alleviate suffering - now appear to conflict with ethical codes in some cases. We have the means to prolong life, but the result may be increased suffering, and the problem of the morality of euthanasia is becoming more pronounced.

- White papers have been drawn up that aim to transform health care service delivery. These focus on aspects such as the decentralisation of responsibility, accountability, power and authority to the lower levels of health care delivery, the greater involvement of the community, the reduction of bureacratic practices that are far removed from the community, and the effective use of resources.

Putting these measures into practice is the issue facing nursing leaders in the South African health care sector.
These changes play a fundamental role in the working environment and ultimately in the workplace of nurses. The following section deals with studies which focused specifically on the workplace of nurses.

\section{Nurses and their workplace}

Various studies have focused on different aspects of the workplace of nurses in South Africa. Manona (2000:5) in a study of causative factors among public sector registered nurses found that determinants whose decrease resulted in increased turnover were promotional opportunities, distributive justice, opportunity for self-development, age and tenure. Better control of turnover could improve the quality of patient care, reduce labour costs and improve employee morale.

Jooste (1997:7) identified six factors that could significantly improve the empowerment of nurses. These factors are the contribution of management structures, power-sharing, participative decision-making, management skills development, motivation and reward strategies, and attributes which characterise an empowered nurse. The analysis of the data revealed the following important elements: decentralisation of power to the lowest possible level; the acknowledgment and if possible the implementation of the suggestions of nurses; the delegation of authority to enhance decision-making; and the design of tasks in a way that promotes independent performance in the workplace.

In a study of occupational burnout among nurses, Erasmus (1995:13) identified excessively heavy workloads, staff shortages and uncertainty regarding role description in the working environment as factors leading to negative feelings, rigidity, anger, apathy and fatigue, all of which impact negatively on performance.

In a study undertaken among registered nurses in the service of local authorities to obtain a perspective on the quality of their working life, Jacobs (1993:4) identified negative factors, such as limited participation in decision-making and limited career opportunities.

Phillips (1993:8) focused on stress in the nursing profession and stress-related 
factors referring to access to adequate support and coping mechanisms. This study revealed that most nurses were coping with the stress and stressors that go with the job, but the most important aspects of stress were related almost exclusively to personnel management. Recommendations included greater emphasis on interpersonal skills and training for nurse managers.

The importance of a participative managerial style in order to promote retention and job satisfaction of professional nurses is emphasised by Stander (1993:3). In this study of participative management in the nursing service, he concludes that no guidelines exist on what participative management is or how it could be implemented in a nursing service. Damane (1992:34) identified salaries, promotional opportunities and working conditions as major sources of dissatisfaction among nurses. This study was supported by a study by Ngcobo (1998:52), in which she used the Nursing Stress Scale, Index of Social Support and Social Support Appraisal Scales. She found that nurses experience medium to low levels of stress. There are no significant differences between registration categories in stress levels and perceived sources of stress reported by nursing staff. In general nursing staff report a high level of satisfaction with the support they receive.

From these studies, one can conclude that the future workplace of nurses in South Africa will be influenced by the following:

$\begin{array}{ll}\text { - } & \text { promotional and self- } \\ \text { development opportunities } \\ \text { delegation of power, authority } \\ \text { - } & \text { and decision making } \\ & \text { motivation and reward } \\ \text { - } & \text { ftrategies } \\ \text { - } & \text { stress } \\ \text { - } & \text { working conditions } \\ & \text { salaries and benefits }\end{array}$

\section{Research methodology}

\section{Target population}

A random sample of 800 nurses was drawn from the 96000 nurses registered with the South African Nursing Council. A response of 102 was obtained (15\%), which could be considered sufficient for the purposes of a valid and reliable scientific statistical analysis.

\section{Questionnaire development}

A similar study was designed, developed and applied in the United States of America. A questionnaire was, based on this study, developed for South African purposes. It focused on the unique challenges of woman in the South African nursing profession. The questionnaire consists of two parts. Part A of the questionnaire focuses on questions on problems that nurses experience in the workplace, how nurses generally feel about their job, possible changes that might provide them with a better workplace, barriers in their career path as women working in the nursing profession, main career expectations and goals, the role of the SANC and the role of woman in the nursing profession. Part $B$ of the questionnaire focuses on biographical information regarding employment, age, family size, marital status, race, income, province, educational level and registration categories.

\section{Statistical analysis}

The data obtained from the questionnaire were analysed with the aid of the Statistical Package for Social Science (SPSS). Frequencies, arithmetic means and standard deviations were used in the initial stages to analyse the data. Further statistical analyses were conducted to determine whether significant differences (at $0,05 \%$ ) existed between the different categories of nurses regarding various work-related issues. When one compares categories (nominal or ordinal data) with regard to their mean scores on interval or ratio data, the appropriate technique is the analysis of variance (ANOVA). This test calculates the F-value and a p-value, where the p-value is a guideline for determining which differences can be considered "real" and which due to chance (Salkind 2000:170).

Internal consistency examines how unified the items are in a test or assessment. One of the most used statistical tools to measure internal consistency is the Cronbach's Alpha which is a correlation coefficient (Salkind 2000:112). The Cronbach Alphacoefficient provided an acceptable reliability score of 0,89 for the whole questionnaire. Normally, an Alpha score of 0,7 or higher is regarded as reliable.

\section{Biographical information}

In this section, a brief overview of the biographical information of the respondents is provided.

- Employment: Of the 102 respondents, $18,1 \%$ were employed in large organisations (5000 employees and more), $39,4 \%$ in medium sized organisations (more than 100 but fewer than 5000 ), $13,8 \%$ in small organisations (fewer than 100 employees), $4,3 \%$ were self-employed, $21,3 \%$ employed by the government, $2,2 \%$ by academic institutions and $5 \%$ by other organisations.

The majority $(80,4 \%)$ of the respondents indicated that they were employed in a full-time capacity, $13,4 \%$ were employed on a part-time basis, $2,1 \%$ were selfemployed, $1 \%$ were unemployed but seeking employment and $3,1 \%$ have retired.

- Age: Only 2.1\% of the respondents were older than 65 years, $32,0 \%$ were between the age of 50 and 64 years, the majority $(43,3 \%)$ were between 40 and 49 years, $18,6 \%$ were between 30 and 39 years and $4,1 \%$ were younger than 29 years.

- Family size: The majority $(53,6 \%)$ of the respondents had children under the age of 18 years living at home, and of this number $53,1 \%$ indicated that they were satisfied with their current childcare arrangements.

- Marital status: The majority $(55,7 \%)$ of the respondents were married while $44,3 \%$ were single, divorced, separated or widowed.

- Race: The majority (49,5\%) of the respondents were white, $46,3 \%$ black. $0 \%$ Asian and $4,2 \%$ coloured.

- Income: The majority $(67,7 \%)$ of the respondents' gross income per month was between R5 000 and R9 999; 14,6\% eamed between R2 000 and R4 999; $10.4 \%$ earned between R10000 and R14999; $3,1 \%$ between R500 and R999; 2,1\% between R500 and R999; and 2,1\% R 15000 or more. None of the respondents earned less than R499.

- Province: The majority $(22,7 \%)$ of the respondents lived in Gauteng; $19,6 \%$ in the Western Cape; $15,5 \%$ in KwaZulu/ Natal; $12,4 \%$ in the Eastern Cape; $10,3 \%$ in the Northern Province; $7,2 \%$ in Mpumalanga; $6,2 \%$ in the North West; 
$5,2 \%$ in the Free State and $1,0 \%$ in the Northern Cape.

- Educational level: The majority of the respondents' $(53,3 \%)$ highest level of education was matric (senior certificate); $21,7 \%$ had a university degree and $20,7 \%$ a post-graduate degree. None of the respondents' level of education was below matric.

- Registration category: The majority (96\%) of the respondents were registered nurses, while $4 \%$ were enrolled and auxiliary nurses.

\section{Results}

In this section, the results of the survey will be discussed by focusing on the following important aspects:

- Issues which cause problems at work

- How respondents generally feel about their jobs

- Possible changes that might provide a better workplace

- Barriers in a nurse's career path as a woman

- Career expectations and goals

- The role of the South African Nursing Council

- The role of women in the nursing profession

A similar study was conducted in 1998 (Erasmus 1998:50-57) and the research results of this study will be compared with those of the 1998 study.

\section{Problems encountered at work}

In this section of the questionnaire, respondents were given a list of various issues (potential problems) and asked to indicate the seriousness of these issues in their workplace. The rating scale ranged from 1 "not at all serious" to 5 "one of the most serious". The responses are reproduced in Table 1 in order of priority. The arithmetic mean is given for each statement.

It seems that this group of respondents feels that the most serious problems that they experience on the job are related to pay benefits and stress and it does not differ from a similar study done in 1998 which showed the

Table 1 Most serious problems encountered at work

\begin{tabular}{|l|l|}
\hline Statement & Arithmetic mean \\
\hline I am not paid what I think my job is worth & 4,68 \\
\hline I need better benefits & 4,45 \\
\hline I am under too much stress & 3,85 \\
\hline I don't have the flexibility to meet family responsibilities & 3,46 \\
\hline I work too many hours & 3,15 \\
\hline
\end{tabular}

same problems. It appears that these aspects were not adequately addressed the past six years by employers and that this should be considered a priority by employers and government.

The issues that respondents indicated as not very serious or not applicable are represented in Table 2 (arithmetic means are again given for each statement).

These issues also correspond to the issues identified by the 1998 survey.

When comparing the different categories of nurses' problems at work, no significant differences were found between the respondents in terms of the types of organisations they were working for, employment (full-time or part-time), income group, age group and having children at home. There were, however, significant differences between the race groups.' As a high score indicates that a problem is experienced to a greater extent, the black respondents experienced each of the problems listed in Table 3 to a significantly greater extent than the white respondents.

Significant differences were also found between respondents from different educational levels with respect to feeling overqualified and acting in positions without receiving the salary attached to those positions. The better qualified a respondent is, the more of a problem this becomes. Graduates and postgraduates are more subject to this problem than respondents with matric or a lower qualification (see Table 4). Salary and benefit adjustments should therefore start with nurses on these educational levels.

Married respondents were more likely to feel that they were acting in a position without receiving the proper remuneration for that position than the single respondents $(F=6,38$ and $p=$ $0,013)$.

\section{Table 2 Less serious problems encountered at work}

\begin{tabular}{|l|l|}
\hline Statement & Arithmetic mean \\
\hline I act in a post without receiving the money for that post grade & 2,97 \\
\hline I worry about losing my job & 2,78 \\
\hline I am overqualified & 2,32 \\
\hline It's hard to find quality child or elderly care that I can afford & 2,60 \\
\hline I don't have the skills to find a better job & 2,12 \\
\hline I travel and sleep away from home too much & 1,70 \\
\hline I am sexually harassed & 1,49 \\
\hline I have lost a job or promotion because of my sex & 1,41 \\
\hline My workplace is male dominated & 1,37 \\
\hline
\end{tabular}

\footnotetext{
${ }^{1}$ For the purposes of the analysis, black and coloured respondents were grouped together.
} 
Table 3 How race groups compare with regard to problems at work

\begin{tabular}{|c|c|c|c|c|c|}
\hline Problems at work & Race & Mean & Std $^{*}$ & $\mathbf{F}^{*}$ & $\mathbf{p}^{* * *}$ \\
\hline I don't have the flexibility to meet family responsibilities & $\begin{array}{l}\text { White } \\
\text { Black } \\
\text { Total }\end{array}$ & $\begin{array}{l}3,02 \\
3,89 \\
3,46\end{array}$ & $\begin{array}{l}1,584 \\
1,650 \\
1,667\end{array}$ & 6,65 & 0,012 \\
\hline It's hard to find quality child or elderly care that I can afford & $\begin{array}{l}\text { White } \\
\text { Black } \\
\text { Total }\end{array}$ & $\begin{array}{l}2.17 \\
3,02 \\
2.60\end{array}$ & $\begin{array}{l}1,160 \\
1,757 \\
1,729\end{array}$ & 5.82 & 0,018 \\
\hline I travel and sleep away from home too much & $\begin{array}{l}\text { White } \\
\text { Black } \\
\text { Total }\end{array}$ & $\begin{array}{l}1,30 \\
2,09 \\
1,70\end{array}$ & $\begin{array}{l}0,662 \\
1,697 \\
1,340\end{array}$ & 8.49 & 0,005 \\
\hline I am overqualified & $\begin{array}{l}\text { White } \\
\text { Black } \\
\text { Total }\end{array}$ & $\begin{array}{l}1,93 \\
2.70 \\
2.32\end{array}$ & $\begin{array}{l}1,162 \\
1,942 \\
1,637\end{array}$ & 5,20 & 0,025 \\
\hline $\begin{array}{ll}* & \text { Standard deviation } \\
* * & \text { F-value } \\
* * * & \text { p-value }\end{array}$ & & & & & \\
\hline
\end{tabular}

Table 4 How the different educational groups compare with regard to problems at work

\begin{tabular}{|c|c|c|c|c|c|}
\hline Problems at work & Education & Mean & Std $^{*}$ & $\mathbf{F}^{* *}$ & $\mathbf{p}^{* * * *}$ \\
\hline I am overqualified & $\begin{array}{l}\text { Matric or less } \\
\text { University degree } \\
\text { Postgraduate degree }\end{array}$ & $\begin{array}{l}1,63 \\
3,25 \\
3,32\end{array}$ & $\begin{array}{l}0,883 \\
2,074 \\
1,827\end{array}$ & 14.02 & 0,000 \\
\hline $\begin{array}{l}\text { I act in a post without receiving the money for that post } \\
\text { grade }\end{array}$ & $\begin{array}{l}\text { Matric or less } \\
\text { University degree } \\
\text { Postgraduate degree }\end{array}$ & $\begin{array}{l}2,17 \\
3,02 \\
2,60\end{array}$ & $\begin{array}{l}2,50 \\
3,00 \\
4,21\end{array}$ & 5,48 & 0,006 \\
\hline
\end{tabular}

\section{General feelings about the job}

In this section respondents were given a list of various options and had to indicate their general feelings about their job. A large percentage $(48,5)$ indicated that they love their jobs, $28,9 \%$ said they like it. while $14,4 \%$ described their jobs as "OK". A very small percentage $(1,0 \%)$ said they dislike it, while $3,1 \%$ indicated that they found their jobs totally miserable and $4,1 \%$ said that they would rather do something else. The majority of the respondents $(77,4 \%)$ are very positive about their jobs. The 1998 survey indicated that a majority of $76,8 \%$ of the respondents were very positive about their jobs.

No significant differences were found between any of the biographical variables and nurses' general feelings about their job.

\section{Possible changes for a better workplace}

In this section respondents were given a list of changes (statements) that might provide them with a better workplace. On a ten-point scale, ranging from 1 (not important) to 10 (very important), they had to rate the importance of each statement. The responses are given in Table 5 in order of priority. The arithmetic mean is supplied for each statement.

The two issues which featured most prominently in this study as well as in the 1998 study were pay related (improving pay scales and being paid according to extra experience, responsibilities and qualifications). Onthe-job training opportunities and medical insurance for all employees also proved to be fairly important for the respondents in this study as well as the
1998 study. To keep nurses in the country and to encourage people to select the nursing profession as a career, remuneration, and more specifically performance-related remuneration, should receive immediate attention.

When comparing the changes that would improve the workplace with the different categories of nurses, no significant differences between respondents from different types of organisations were found. When comparing full-time and part-time employees, however, two significant differences were found. Equal opportunity in the workplace $(F=5,37$, $p$ $=0,023)$ and paid leave to care for newborns or seriously ill relatives $(\mathrm{F}=$ $5,01, p=0,028$ ) become more important to full-time nurses.

While there is no significant difference 
are given in Table 8 (the percentage of the

\begin{tabular}{|l|l|}
\hline Statement & Arithmetic mean \\
\hline Improving pay scales & 9,23 \\
Being paid according to extra experience, responsibility and qualifications & 9,02 \\
On-the-job training opportunities to learn new skills & 7,62 \\
Medical care insurance for all employees & 7,59 \\
Equal opportunity in the workplace & 7,07 \\
Retraining opportunities & 7,03 \\
More responsibility in deciding how to do their jobs & 6,83 \\
Student loans for acquiring new skills & 6,67 \\
Paid leave to care for newborns or seriously ill relatives & 6,23 \\
More flexible working hours (6,22) & 6,22 \\
Job sharing opportunities & 5,55 \\
Informing men about what sexual discrimination means & 5,58
\end{tabular}
respondents choosing an option are also given).

Job satisfaction and recognition were the most important career expectations indicated by respondents, which corresponds to the findings of the 1998 survey.

When comparing categories of nurses' career expectations and goals, it was found that full-time and part-time nurses differ significantly with regard to their expectations for promotion and recognition. Promotion $(F=13,6, p=0,000)$

between age groups in terms of what changes would make their workplace better, the two race groups did differ on a few aspects. These are indicated in Table 6.

From Table 6, it is clear that black nurses need more support to care for children, dependants and seriously ill relatives than white nurses. They also need equal opportunities in the workplace, on-thejob training and job sharing opportunities more than white nurses, probably because of some remaining imbalances from the past.

\section{Career path barriers}

In this section, respondents were firstly asked to indicate whether they perceive barriers in their career paths as women working in the nursing profession that prevent them from achieving their full career potential. The majority $(61,4 \%)$ of the respondents indicated that they do not perceive any barriers, while $38,6 \%$ indicated that they do. On this Yes/No answer, there is only one significant difference with regard to the biographic variables, namely race. Only $23,8 \%$ of the white respondents felt that there are barriers in their career path, while 53,8\% of the black respondents felt this way $(\mathrm{F}$ $=7,723, p=0,005$ ). Secondly, respondents were asked to indicate the importance of possible barriers which they believed impeded their career prospects by using a scale of 1 (not important) to 10 (very important). Table 7 gives these barriers in order of priority (arithmetic means are also indicated).

Major barriers indicated by the respondents in this study as well as the 1998 study are a lack of recognition and respect for work completed and low salaries which cannot support child-care payments.

In comparing the different categories of nurses with regard to barriers in their career paths, the race groups showed two significant differences, namely in lack of recognition and respect for work completed $(F=7,08, p=0,009)$ and in prevention from being creative and innovative $(F=4,37, p=0,040)$. In each case the black respondents were finding the specific item more of a barrier than the white respondents. Married respondents found the lack of flexibility in working hours $(F=4,86, p=0,030)$ and the inadequate allowance made for family commitments $(F=5.29, p=0,024)$ more of a problem than those respondents who are not married. As can be expected, those respondents with children at home also found the inadequate allowances made for family commitments to be more of a problem than those without children $(F=5,57, p=0,021)$.

\section{Career expectations and goals}

In this section of the questionnaire, respondents were required to indicate their expectations and goals for their career. They could indicate more than one possibility from the list provided. The main expectations in order of priority and recognition $(F=4,56, p=0,048)$ are more important to full-time employees than to part-time employees. The respondents aged 39 and younger showed a higher expectation for promotion opportunities, while $81 \%$ of the young group indicated promotion as one of their main expectations, compared with the $64 \%$ of the 40 to 49 year old group and $45 \%$ of those older than 50 years ( $F$ $=7,5 ; \mathrm{p}=0,023$ ). The race groups showed the biggest difference in terms of career expectations. Black respondents were more likely to have mentioned promotion ( $\mathrm{F}=18,57, \mathrm{p}=0,000)$; power and status $(\mathrm{F}=24,61, \mathrm{p}=0,000)$; professional support $(F=15,5, p=0,000)$ and recognition $(F=11,1, p=0,001)$. White respondents were more likely to have mentioned a balanced professional/ private life $(F=5,09, p=0.024)$. Education and marital status had no influence on nurses' career expectations. Those respondents with the lowest income (R500 - R4 999) were the least concerned with job satisfaction $(F=6,68, p=0.035)$ and promotion $(F=6,68, p=0,035)$. Those respondents with children at home indicated greater expectations with regard to promotion $(\mathrm{F}=16,99, \mathrm{p}=0,000)$, power and status $(F=11,54, p=0,001)$, and professional support $(F=9,18, p=0,002)$.

Respondents were also asked to indicate whether their goals and objectives were different from those of men in their organisation. They were also asked to state whether they had modified their career expectations since graduation. 


\begin{tabular}{|c|c|c|c|c|c|}
\hline Workplace changes & Race & Mean & Std & $\mathbf{F}^{*}$ & $\mathbf{p}^{* * *}$ \\
\hline Information about support for child or dependant care & $\begin{array}{l}\text { White } \\
\text { Black } \\
\text { Total }\end{array}$ & $\begin{array}{l}3,26 \\
5,14 \\
4,21\end{array}$ & $\begin{array}{l}3,017 \\
3,927 \\
3,612\end{array}$ & 6.25 & 0.014 \\
\hline Ensuring equal opportunity in the workplace & $\begin{array}{l}\text { White } \\
\text { Black } \\
\text { Total }\end{array}$ & $\begin{array}{l}5,68 \\
8,42 \\
7.07\end{array}$ & $\begin{array}{l}1,160 \\
1,757 \\
1,729\end{array}$ & 19,74 & 0,000 \\
\hline Paid leave to care for newborns or seriously ill relatives & $\begin{array}{l}\text { White } \\
\text { Black } \\
\text { Total }\end{array}$ & $\begin{array}{l}5.05 \\
7,41 \\
6,23\end{array}$ & $\begin{array}{l}0.662 \\
1,697 \\
1,340\end{array}$ & 10,50 & 0.002 \\
\hline On-the-job training opportunities to learn new skills & $\begin{array}{l}\text { White } \\
\text { Black } \\
\text { Total }\end{array}$ & $\begin{array}{l}6.77 \\
8,40 \\
7,62\end{array}$ & $\begin{array}{l}1,162 \\
1,942 \\
1,637\end{array}$ & 6.82 & 0.011 \\
\hline Student loans for courses to give me new job skills & $\begin{array}{l}\text { White } \\
\text { Black } \\
\text { Total }\end{array}$ & $\begin{array}{l}5,82 \\
7,72 \\
6,67\end{array}$ & $\begin{array}{l}3,412 \\
3,089 \\
3,376\end{array}$ & 7,43 & 0,008 \\
\hline Giving employees more responsibility to decide how they do their jobs & $\begin{array}{l}\text { White } \\
\text { Black } \\
\text { Total }\end{array}$ & $\begin{array}{l}5.82 \\
7.80 \\
6.83\end{array}$ & $\begin{array}{l}3,172 \\
2.849 \\
3,156\end{array}$ & 9,79 & 0,002 \\
\hline Job sharing opportunities & $\begin{array}{l}\text { White } \\
\text { Black } \\
\text { Total }\end{array}$ & $\begin{array}{l}4,48 \\
6.52 \\
5.55\end{array}$ & $\begin{array}{l}3,131 \\
3.650 \\
3.546\end{array}$ & 7,88 & 0,006 \\
\hline
\end{tabular}

* Standard deviation

** F-value

*** $\quad$ p-value

\section{Table 7 Career path barriers}

\begin{tabular}{|ll|}
\hline Statement & Arithmetic mean \\
\hline Lack of recognition and respect for work completed & 7,57 \\
Low salaries which cannot support child-care payments & 6,83 \\
Little allowance made for family commitments & 6,48 \\
Lack of flexibility in working hours & 5,90 \\
Prevented from being creative and innovative & 5,85 \\
Required to work long hours & 5,49 \\
Restriction on types of work given, thus limiting experience & 5,11 \\
Lack of female mentor support & 4,42 \\
Perceived gender bias by supervision & 2.99 \\
Male culture within your organisation & 1.96 \\
\hline
\end{tabular}

The majority $(79,1 \%)$ of the respondents did not believe that their goals and objectives were different from those of men in their organisation, while $70,7 \%$ of the respondents had modified their career expectations since graduation. Factors indicated by respondents which have changed their previous career expectations range from a lack of recognition and salary, changes in nursing as a job, working for a medical funder, remuneration, family commitments, stress, lack of support from the organisation, studies, theatre experience, affirmative action, specialisation, promotion, racism, children, lack of time for family, working hours, low standard of nursing care, becoming more mature, and risk-related factors such as AIDS.

Respondents were also required to present their long-term career goals. The responses varied from being able to lecture, to becoming involved in child psychology, to being promoted to the position of trustee on the medical board. to doing clinical research, to furthering their studies, to being promoted, to opening their own clinic, to becoming computer literate, and to feeling secure in their jobs.

\section{The role of the South African Nursing Council}

The majority $(89,1 \%)$ of the respondents believe that the South African Nursing Council has a role to play in providing more assistance to women members with their careers. Respondents were requested to indicate which services the Council could provide for those members who had temporarily left the profession. Respondents could indicate more than 
Table 8 Career expectations and goals

\begin{tabular}{|l|c|}
\hline Main expectations & Percentage \\
\hline Job satisfaction & 93,1 \\
Recognition & 80,2 \\
Balanced professional/private life & 76,2 \\
Professional support & 73,3 \\
Remuneration & 66,3 \\
Promotion & 59,4 \\
Power and status & 31,7 \\
\end{tabular}

about what it is like to be a working woman in the nursing profession and $90,1 \%$ of the res pondents answered this question.

The four most prominent issues that emerged from the responses were

Table 9 Services required from the South African Nursing Council

\begin{tabular}{|l|l|}
\hline Service & Percentage \\
\hline Annual refresher courses & 85,1 \\
A network group of professional woman mentors & 53,5 \\
Greater discounts on membership fees than currently offered & 51.5 \\
Discussion group(s) & 46,5 \\
Other & 12,9 \\
\hline
\end{tabular}

one option from the list provided. The services required in order of priority are given in Table 9. In each case, the percentage of respondents choosing an option is given.

"Other" included attention to real problems by the South African Nursing Council, support of private nurse practitioners, support groups in working situations, involvement of retired nurses, workshops, and re-entry to the profession.

In the 1998 study, respondents also put annual refresher courses as their first priority. The other services were ranked differently in this study, however. Discussion groups were ranked second, greater discounts on membership fees than currently offered were ranked third and a network group of professional women mentors were ranked fourth.

When comparing the different categories of nurses' view of the role of the South African Nursing Council, two significant differences were evident. Black respondents were more likely to require that discussion groups be set up (63\%) than white respondents $(34 \%)(\mathrm{F}=7,7, \mathrm{p}$ $=0,008$ ).

\section{Feedback on what it is like to be a working woman in the nursing profession}

In this section, respondents were asked what would they tell President Mbeki

related to:

$$
\begin{aligned}
& \text { - } \quad \text { better remuneration } \\
& \text { - } \quad \text { better conditions of service } \\
& \text { negative impact of AIDS on } \\
& \text { their career }
\end{aligned}
$$

\section{The role of women in the nursing profession by the year 2005}

In this section respondents were asked how they see the role of women in the nursing profession by the year 2005 . The majority view was one of optimism, although some were worried about good nurses leaving the country and standards dropping. Those who expressed pessimism tended to be in state hospitals and emphasised the fact that fewer young people are interested in becoming nurses, and there is an increasing workload on existing staff.

\section{Discussion of research done in 1998 and 2003}

Table 10 compares the outcome of this research with that of the 1998 study (Erasmus 1998:50-57).

The problems that nurses experience at work have not changed from 1998 to 2003. Nurses should receive better remuneration and benefits and their stress levels need attention.

The ranking for possible changes for a better workplace changed in 2003 . Being paid according to extra experience, responsibility and qualifications and improving pay scales were ranked first and second respectively in the 1998 study, while the 2003 study ranked them second and first respectively. On-thejob-training opportunities were ranked third in both studies.

The ranking for barriers in the workplace changed in 2003 . Low salaries which cannot support childcare payments and lack of recognition and respect for work completed were ranked first and second respectively in the 1998 study, while the 2003 study ranked them as second and first respectively. Restriction on the type of work given thus limiting experience (ranked third in 1998) was replaced by inadequate allowance for family commitments in 2003. These barriers again stress the need for better performance-related remuneration. Bigger allowances should also be made for family commitments, which should lower nurses' stress levels.

Job satisfaction and recognition remain the two most important career expectations and goals for nurses. Annual refresher courses and forming discussion and mentor groups are important suggestions made by nurses to the SANC.

\section{Conclusions}

From the above results it is evident that pay-related issues still dominate as the main problem at work. This is in line with international sentiments regarding the issue of remuneration. Significant differences were found when race groups were compared with regard to problems at work. Black respondents experience each of the following problems to a greater extent than white respondents: "I don't have the flexibility to meet family responsibilities"; "It's hard to find quality child or elderly care that I can afford"; "I travel and sleep away from home too much", and "I am over qualified". Significant differences were also found when educational levels were compared with problems at work. The better qualified a respondent is, the more of a problem this becomes.

In general the respondents had a positive attitude towards their job, which leaves the general impression that nurses still regard their jobs as something they do for the sake of a service to the community and not only for the money they earn. 


\begin{tabular}{|c|c|c|c|}
\hline 1998STUDY & & 2003 STUDY & \\
\hline $\begin{array}{l}\text { Problems at work } \\
-\quad \\
\text { - } \\
\text { - } \quad \text { Better remuneration needed } \\
\text { Too much stress }\end{array}$ & $\begin{array}{c}\text { Ranking order } \\
1 \\
2 \\
3\end{array}$ & $\begin{array}{ll}- & \text { Better remuneration needed } \\
\text { - } & \text { Better benefits needed } \\
\text { - } & \text { Too much stress }\end{array}$ & $\begin{array}{c}\text { Ranking order } \\
1 \\
2 \\
3\end{array}$ \\
\hline $\begin{array}{l}\text { Possible changes for a better workplace } \\
\text { Being paid according to extra } \\
\text { experience, responsibility \& } \\
\text { qualifications } \\
\text { Improving pay scales } \\
\text { - } \quad \text { On-the-job training opportunities }\end{array}$ & 2 & $\begin{array}{ll}\text { - } & \text { Improving pay scales } \\
\text { - } & \text { Being paid according to extra } \\
\text { experience, responsibility \& } \\
\text { qualifications } \\
\text { On-the-job training opportunities }\end{array}$ & $\begin{array}{l}1 \\
2 \\
3\end{array}$ \\
\hline $\begin{array}{l}\text { Barriers in the workplace } \\
\text { - } \quad \text { Low salaries which cannot } \\
\text { support childcare payments } \\
\text { Lack of recognition and respect } \\
\text { for work completed } \\
\text { Restriction on type of work given, } \\
\text { thus limiting experience }\end{array}$ & $\begin{array}{l}1 \\
2 \\
3\end{array}$ & $\begin{array}{l}\text { Lack of recognition and respect } \\
\text { for work completed } \\
\text { Low salaries which cannot } \\
\text { support childcare payments } \\
\text { Little allowance made for family } \\
\text { commitments }\end{array}$ & $\begin{array}{l}1 \\
2 \\
3\end{array}$ \\
\hline 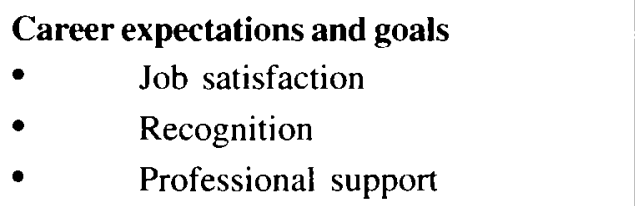 & $\begin{array}{l}1 \\
2 \\
3\end{array}$ & $\begin{array}{l}\text { Job satisfaction } \\
\text { Recognition } \\
\text { Balanced professional/private life }\end{array}$ & $\begin{array}{l}1 \\
2 \\
3\end{array}$ \\
\hline $\begin{array}{l}\text { Suggestions to SA Nursing Council } \\
\text { - } \quad \text { Annual refresher courses } \\
\text { Discussion groups } \\
\text { - } \quad \begin{array}{l}\text { Greater discounts on membership } \\
\text { fees }\end{array}\end{array}$ & $\begin{array}{l}1 \\
2 \\
3\end{array}$ & $\begin{array}{l}\text { Annual refresher courses } \\
\text { Network group of professional } \\
\text { women mentors } \\
\text { Greater discounts on membership } \\
\text { fees }\end{array}$ & $\begin{array}{l}1 \\
2 \\
3\end{array}$ \\
\hline
\end{tabular}

Apart from the two pay-related issues (improving pay scales and being paid according to extra experience, responsibilities and qualifications), there were other prominent issues that could improve the workplace. High on the list were training opportunities, medical insurance for all employees and equal opportunities in the workplace. These issues should be addressed as a matter of great urgency. Equal opportunities in the workplace and paid leave to care for newborns or seriously ill relatives were more important to full-time nurses. The following changes were more important to black respondents than to white respondents: information about support for child or dependent care, ensuring equal opportunity in the workplace, paid leave to care for newborns or seriously ill relatives, on-the-job training opportunities to learn new skills, student loans for courses to provide new job skills, giving employees more responsibility for how they do their jobs and job sharing opportunities.

A lack of recognition and respect for work completed and low salaries were the major career path barriers identified by respondents. In comparing the different categories of barriers in their career paths encountered by nurses, the race groups showed two significant differences, namely a lack of recognition and respect for work completed and prevention from being creative and innovative. In each case the black respondents were finding the issue more of a barrier than the white respondents. Married respondents found the lack of flexibility in working hours and inadequate allowances made for family commitments more of a problem than those respondents who are not married. As can be expected, those respondents with children at home also found inadequate allowances made for family commitments to be more of a problem than those without children.

Long-term goals in the nursing profession covered a wide range of responses which supported the view that nurses do see the nursing profession as one in which they can realise their own dreams and ideals. However, nurses expressed concern about the 
remuneration they receive, the recognition they receive as a profession, their conditions of service and the whole issue around the handling of AIDS and their exposure to the pandemic. Pessimism was expressed about good nurses leaving the country and the profession, the lowering of standards, the fact that fewer nurses are available and the increasing workload on existing staff. Significant differences were reported between black and white nurses. Black respondents were more likely to have mentioned promotion, power and status, professional support and recognition. White respondents were more likely to have mentioned a balanced professional/ private life.

By adressing these aspects of the working life of woman in the nursing profession in South Africa, a contribution will be made not only to the retention of nurses in the country, but also to the improvement of the general standard of health care of the country.

\section{References}

DAMANE, TVP 1992: Factors influencing job satisfaction or dissatisfaction among female registered nurses employed by the Department of Health, Transkei. Unpublished MSc Dissertation, University of Natal, Dalbridge.

ERASMUS, BJ 1998: Nursing professionals' views on the workplace. Curationis. 21(4):50-57.

ERASMUS, L 1995: Occupational burnout amongst nurses in a private psychiatric hospital. Unpublished MA Dissertation, Rand Afrikaans University, Auckland Park.

JACOBS, IP 1993: A perspective on the quality of work-life for registered nurses employed by local governments. Unpublished M(Cur), University of South Africa, Pretoria.

JOOSTE, K 1997: A model for empowering nurses - a management model. Unpublished D Litt et Phil thesis, University of South Africa, Pretoria.

JOOSTE, K 2003: Leadership in health services management. Cape Town: Juta.

MALAN, M 2004: SA verloor só duisende verpleërs. Rapport. 20 Junie: 19.
MANONA, WW 2000: Causative factors of turnover among public sector registered nurses. Unpublished, MA Dissertation, University of Stellenbosch, Stellenbosch.

NGCOBO, MB 1998: Social support, stress and health in the nursing profession. Unpublished MA Dissertation, University of Port Elizabeth, Port Elizabeth.

PHILLIPS, N 1993: Stress and stress management in nursing managers. MSc dissertation, University of Natal, Dalbridge.

SALKIND, NJ 2000: Exploring research. $4^{\text {th }}$ ed. Upper Saddle River, New Jersey: Prentice Hall.

STANDER, J 1993: Participative management in a nursing service. MCom. Rand Afrikaans University, Auckland Park.

STATISTICS SOUTH AFRICA 2001: Labour Force Survey, February. 